\title{
Leadership of Sanusi Daris in the Dynamics Community of Duri Enrekang Regency
}

\author{
Abd. Rahman Pilang \\ University " 45 " of Makassar - Indonesia 90125 \\ Accepted: April 03, 2013 Published: May 14, 2013 \\ Doi:10.5296/jsr.v4i2.4067ＵRL: http://dx.doi.org/10.5296/jsr.v4i2.4067
}

\begin{abstract}
This is a sociology study discussing the leadership of Sanusi Daris in various statuses he was entitled, his carrier was started as a teacher then involved in an independence maintenance movement as a commander of TNI (National Army of Indonesia). Yet, finally he chose to join with Kahar Muzakkar of DI-TII Movement (Darul Islam - Tentara Islam Indonesia) in Baraka, Enrekang Regency. For the purpose, this writing describes, (1) Profile of Sanusi Daris as an educator, fighter; (2) His position as an agent of change; (3) Perception of people against his personality and leadership. Data or information obtained through: interview, participation observation, documentation analysis, life history analysis, and folklore analysis. Methodology used is qualitative descriptive approach. The results of the study show: (1) People of Duri is a community which give special attention to recruitment process of their leaders as for they view that a leader is identical with benefit and prosperity of the people; (2) Sanusi Daris is a charismatic leader; (3) Sanusi Daris is an agents of change, the enforcement of Islam Shari'a has motivated the change in religious system which then lead to socio-cultural changes; (4) People of Duri percept Sanusi Daris as a role model, a leader of trustworthy, and responsible.
\end{abstract}

Keyword: Leadership, Educator, Fighter, Charismatic leader, Agent of socio-cultural change

\section{Introduction}

Leader and leadership are always interesting cases to be discussed as for it has great influence in the community or people. Many people argued that influence of a leader for a community or country is very much determinant. A leader with various background statuses and roles can enhance spirit, proud, or cautious and fear of doing anything. Leader also viewed as the main factor to bring success, or improvement, or failure, and backwardness of a community or a country. Throughout the history of the human race, so many countries found to reach rapid progress or experience painful setback, even deterioration, due to the role of their leader.

Leadership is a character, a long-term process. The process has two stages initiated with the self-leadership ability. Without self-leadership ability, it is impossible to come to the second stage, lead others. "The power of a leader is determined by his ability to serve the people, not ability to tie the will of the people" (Rivai, 2004). Please note that every word spoken, every step taken, will give different influence to people around us. It means that the behavior 
exhibit will lead someone to be a true leader or fake leader. Besides, a leader should hold principles. A leader no matter typical and style used in his leadership, all are dependent on the principles believed. On the other hand, environment could bring somebody become a follower only, realized or not. Somebody without principles to hold is easily provoked, as for we will always walk in the meadow of booby traps, booby traps effect your mind (Agustian, 2002).

This is a writing about a local figure who had an important role in a remote land, an inland of South Sulawesi which famous as Tanah Duri, Enrekang Regency, that is Sanusi Daris, one of a leader in the teaching of DI-TII, who took Kahar Muzakkar's position as the Highest Commander of DI-TII after his death (Sialla, 2005). He is considered rebel by the country, but loved and respected by people of Tanah Duri, a place where he was born, grown, and entitled various statuses and roles. At start, he was a teacher, then involved himself in a movement of fight to maintain independence. Whenever physical revolution will come to success, he chose to leave his position as a company commander of Wolter Monginsidi Battalion under the command of Andi Sose. The battalion was inaugurated as a member of Indonesian National Army (TNI) in 1952 and positioned in Makale Tanah Toraja. Did not take a part in the inauguration, then Sanusi Daris joined Kahar Muzakkar and together proclaimed the establishment of DI-TII in Baraka district Enrekang Regency in 1953.

It is getting interesting to be discussed that he who was only a company commander in Wolter Monginsidi Battalion, not a famous leader of fighters, but immediately got an important position to lead troops of a big revolutionary movement of a newly born country.

Then raised questions whether a charismatic performance of Sanusi Daris who is ex-official of DI-TII was innate (talent), or due by the influence of the social system where he born and grown up till he became one of DI-TII leaders, or others factors were there, for example unique experience during entitling various statuses in his life.

Therefore, this study is meant to give systematic and comprehensive description and explanation of how Sanusi Daris played various statuses and roles throughout his life history so that he became a charismatic leader for Duri community, Sanusi Daris's profile as an educator, fighter and rebel, and as agent of socio-cultural changes. People perception on his behavior and leadership.

\section{Research Methodology}

\subsection{Research Location}

This research was performed in Enrekang Regency, Pinrang Regency, City of Pare-Pare and City of Makassar and other areas where informants are found to get trace back information on the leadership of Sanusi Daris, either as a teacher, or when he involved in DI-TII movement so that he was considered as a rebel. Similarly, information on the time of his wanderings, periods of negotiations, time when the loss of his loyal followers, and eventually arrested, detained, prosecuted, until released.

\subsection{Nature of the Research}

This is a qualitative research (Muhadjir, 2006) aiming at finding and describing people's view and knowledge about personality and leadership of Sanusi Daris either as an educator, fighter, or when he was suspected as rebel. Qualitative approach was selected in this study by the 
consderation that the approach is more appropriate to study things of phenomenon and reveal hidden facts behind the phenomenon ( Hasniati, 2006). Qualitative research design is flexible, unorganized and go with the flow, for example in the purpose, subject, sample, data source, etc.

\subsection{Research Instruments}

Main characteristic of data collection in qualitative research is participative observation and interview technique. By the data collection technique, the role of researcher is determinant to the whole scenario (Moleong, 1996). Thus, main instrument of the research is the researcher himself, and as the planner at the same time, annalist, data interpreter and then a reporter for the result of the research. Therefore, definition of "research instrument here is already appropriate, noting that the researcher is everything for the research process" (Muhadjir, 2006)

Role of human as research instrument can be useful if meet following criteria: the researcher should be responsive, having good ability to adapt, emphasizing on the wholeness (making use of imagination and creativity and viewing this universe as the whole), having prominent ability to place himself based on the broader knowledge, processing data as soon as possible, making use of chance to clarify and summarize ang making use chance to look for unusual and idiosyncratic respond (Moleong, 1996).

\subsection{Research Informants}

Research Informant meant is someone to whom expected to give information on the research subject due to the tight relationship between them for example as friend, family, subordinate or superior, partner or as anything with any position. Some of the informants are still reside in Enrekang Regency and some others have moved and stayed in outside areas such as Pinrang, Makassar and Jakarta. Whereas, procedure to decide informant is done based on the need (purposive technique), as well as the number of informants, determined based on the surfeit of information obtained.

\subsection{Data Collection Techniques}

Interviews

Data collection technique used in the research is unstructured in-depth interview technique. The technique was performed through direct interview between interviewer and interviewee. This is the strength as well the weakness of the technique, as so many information needed in scientific social research are obtained from informants through direct interview, as well as create a conducive climate to foster trust so that respondents are willing to give honest information, so negative aspect can be covered. For example information related to opinion, attitude towards religion and minority groups and political view, sometimes some people refuse to talk the truth, as result data are not valid.

Observation

In social research, observation technique mostly used is participative observation or involved researcher. The researcher is directly involved in community life where the research conducted. Becker mentioned research with involved observation is done by more or less directly take a part in the life of the subject. The research should involve with the research subjects in their daily life, see what they do, when, with whom, and in what condition, and ask them about what they do. 
It is a rare case when a directly involved researcher only does slight observation without interview or merely informal talk to confirm what he/she sees. Sometimes, he/she use document to support data obtained from the observation. Therefore, participative observation and interview complete each others. This needs spontaneous commentary in behaving in their natural environment. Thus obtained a comprehensive reference on the subject as well as in-depth view by comparing what they say with what they do during spontaneous environment (Arikunto, 1996).

Indeed, the research objecting at the the past time happening can not be directly observed, but we can observe community condition where the happening took place. Therefore, we can draw conclusion or interpretation on what really happened at that time. And so can observe the condition of the place of unique happening experienced by the subject during his life and when various statuses and roles he had entitled.

Documentation analysis

Participative observation and in-depth interview can be completed by literary studies such as analysis of autobiography, memoir, diary, personal letters, court notes, newspaper news, magazine articles, brochures, bulletins, and photos (Mulyana, 2006). Some researches even heavily rely on the (combination of) those documents, without interview, if data in those documents considered enough and complete.

Schatzman and Strauss (Mulyana, 2006) asserted that historical documentations are important material in qualitative research. Both said, as part of field method, researcher can analyze historical documents and other secondary sources, as most situation studied have its own history and those documents explain partial aspect of the situation. On its relation, autobiography, diary, and personal letters are usually the most important. However, we have to treat published autobiography carefully, as for possibly that autobiography is meant for the fame by the writer, as well as to feature the good sides ( as a hero, man dedication, man of success, man of intelligence, generous, etc.), and cover the bad sides.

Research will need documentation data, in the form of biography or dairy and people who get acquaintance or communicate with him formally or informally. In various meetings between Sanusi Daris and college students team of HPMM led by H. Muchtar Ro-E., or team formed by Kodam XIV Commander Hasanuddin which is General Brigadier Abdul Asis Bustan, the researcher got many notes and information from them.

Life history analysis

Life history analysis technique is when the researcher will get insight trough reaction, response, interpretation and vision of the people to the subject.

By studying data on the individual experience in the life of certain community, the researcher could deepen the qualitative definition about detail of the problems being studied from individual, certain group or community, which can not be obtained through observation technique or through questionnaire (Muhadjir, 2006).

By using this technique, we will obtain complete or trusted view from anybody experience of living together with Sanusi Daris as the subject of the research. Because there is no written biography published, then it is considered that the persons who closely knew about his life story when he was a teacher, when involved in the fight to maintain independence.when he was suspected as a rebel, when he was sent to prison till released, are they who once become 
his students, his fellow teachers, his followers and troops, his superiors, his friends and families, and any other persons who have such information, for example from military department and government.

Folklore analysis

Definition of "folklore " is identical with oral story or folktale. It is an inherited culture maintained among people. "A tale or lore is generally told in the form of the story through generations" (Abdullah et al., 2006).

The process of story or tale inheritance can be a vertical process, for example from the grandfather / grandmother to the child (father), and subsequently the father to the child, and so on down. Also can be a widening (horizontal) process from somebody to his/her friends, from friends to the close neighbors, then neighbors beside, an so on widen to all the people of the village even to the nearby village and finally everybody knows.

Part of culture which can be called as folklore can be language, traditional saying (proverb and etc.), puzzle, prose such as mite, traditional theater; traditional game; traditional belief, traditional architecture, fine art, and painting; traditional music, pantomime, etc.

By using the method or technique, many data on the inherited custom and belief can be obtained from people who get the information from their parents during their life. Ancient beliefs as part of cultural life can only be obtained by mean of the technique, for sure also supported with interview technique, to father then to children, or horizontally or somebody who got the story from his/her grandfather (grandmother) passed through friends, neighbors, close neighbors, neighbors beside, and so on passed from village to village. This folklore is meant to get historical sources or proves of oral story continually exist among people. Problems in the oral tale is that it is already happened long time ago, can be hundred years, or a century ago. To seek for such information, can not be done using interview or observation technique, as for it has happened for ages and it might that the proves already gone by the age (Arikunto, 1996).

\subsection{Data Analysis Techniques}

Data obtained are grouped based on the need, they are: primary data, secondary data, or complementary data. And data in the form of information can be words, explanations or opinions (interpretations) and or perceptions, thoughts, wills and believes of the subject about something beyond the subject itself. The data are analyzed, then drawn specific conclusion followed by interpretation and the position of specific conclusion of the research result towards grand concept: whether it is sharpening, modifying, or enriching the concept.

Noting that it is a qualitative research, then analysis done starting from researcher enter the real field (Muhadjir, 2006). It means that analysis last throughout the research process, or in another word it is ongoing during data collection. (Mulyana, 2006)

\subsection{Research Objectives}

Main object of the research is the leadership of Sanusi Daris since he was a teacher, fighter, or rebel when he joined Kahar Muzakkar, or as a suspect or prisoner till released. Information obtained from people who experience of living together with him trough in-depth interview, field observation in the region or place where he stayed during he played various statuses as discussed above. Beside, in order to understand more about the object, documentation analysis was also performed, to support data validity. 
Research was also conducted to get a view on socio-culture of Duri people, noting that figure who is the subject in the research was one of its members. There he was born, grown up, and entitled various statuses and roles. It needs to trace socio-cultural system of his community to obtain information whether it has influence on his personality and leadership in running his responsibility.

3. Result and Discussion

\subsection{Sanusi Daris as an Educator}

Sanusi Daris who was in daily life called as "Utji" was born in 1925 in Kalosi of Mata Allo Village, Alla District, Enrekang Regency, from a husband and wife, Gata or Nene' Kupi or Nene' Hawa (father) and Tiha (mother). He was still in the shame descendant of Nene' Bolang, Indigenous Stakeholder of Alla Kingdom in the past time. The first king of Duri Kingdom was Cirinna Sambo Langi' (Abdullah, 1986). This showed that Sanusi Daris still had family bond with descendants of the kings of Duri Kingdom. The origin of Sanusi Daris as a descendant of noblemen was proven that he could get a good education by going to school at the time of Dutch colonialism. At that time, only children of noblemen or descendants of indigenous stakeholders allowed to go to school. Children of common people were not allowed yet.

Sanusi Daris started to teach since the era of Japan colonialism, after Indonesia proclaimed its independence and established as a sovereign country, then he just pointed as a teacher of Sekolah Rakyat (SR) and was asked to teach in Kalosi in the age of about 20 years old. View months teaching in SR of Kalosi, he was moved to Malua, which was the center of Duri Kingdom. When running his mandate as a teacher in Malua, Sanusi Daris got acquaintance with one of public figures of Muhammadiyah from Pasui (center of Buntu Batu Kingdom, fragmentation of Duri Kingdom) named Sialla. At that time Sialla was actively spreading religious belief Muhammadiyah until Malua and Buntu Lamba. "On the merit of Sialla then sub-branch of Muhammadiyah in the Duri area was established that is Buntu Lamba Sub-branch, the first organization to born in Tanah Duri" (Sialla, 2005).

As a teacher, Sanusi Daris mostly showed different behavior from most teachers at his time. As stated by his two students, Salija (68 years old) and Ms.St Hanisah (68 years old), that he was always in the attractive and impressive performance when teaching. He had a high empathy and affection, gave sincere love, so that all of his students was not in the feeling of dealing with a teacher, but its more dealing with a loving father or brother.

Such attitude and behavior made all his students to be respectful and loving to him. Such attitude has created harmonious relationship between students and teacher. Indeed "... respect is important to create a positive relationship," (Pattan, 1998) Then positive relationship will bring positive energy to both sides in communication. This energy raise creativity and innovation which then create many ideas in the daily life.

Lesson he taught was easily understood. He educated with affection, with conscience. The concept of "People need people" dominated his teaching interaction (Departemen Pendidikan Nasional ,1979). Above described attitude, it is very important for teacher in running his role as it effects the brain of the students. Why is it so? In fact, a teacher whose impressive performance in teaching will create what so called as "Optimum Learning State (OLS)" commonly known as " Kondisi Belajar Optimal”. (Stine, 2002). 
Please highlight that in learning we need to be happy, which is the main factor to determine quality and quantity of learning. This happiness can enhance will, whole involvement, and then create meaning, understanding, and value that brings happiness of the student itself"' Concept of "happiness in learning" is discussed here as comparison to the fact of past time teaching and learning activity which already had modern learning principles as implemented by Center for Accelerated Learning of Lake Geneva which established 57 years after. Even the concept will be implemented in the next three years in Indonesia.

Recently, a research conducted on Neurolingusitics Program (NLP), a research on how brain arrange information. The program studied the relationship between language and behavior and can be used as reference to create understanding relationship between students and teachers. It showed that suggestion can and exactly effect the result of learning situation, and every detail gives positive or negative suggestion. Some of the techniques are: "to sit students comfortably, increase individual participation, and provide trained teachers in the the practice of suggestive learning" (De Porter and Hernaki, 2001). Years ago, principles of the research on NLP has been naturally implemented by Sanusi Daris in the activity of his teaching, although it was not the result of his reading and learning. Teaching practice he performed, is much more natural talent as a picture of his personality. Sanusi Daris as a teacher has charming smile, and he had never laugh loudly, his well arranged and only as needed speak in fact creates a "happy learning" (De Porte and Hernacki 2001) and it was the way to success.

Sanusi Daris had never talked useless, as stated by Paita Halim (66 years old), one of his students, who then became his guard in DI-TII. Everything may be innate which is grace for him to be a leader of charismatic. Please note that not all leaders have such characteristics. It can be created if everybody realize that leader is a very strategic position in the community. However, smile can be crated, one without sincerity will be discovered Smile meant here is the one from the bottom of the heart, sincere, and and unconditional, as for such smile will create natural emotional relationship, not illusive smile (De Porter, et al.,2002)

Paying attention to the ways of Sanusi Daris in running his role as a teacher as stated by his students, shows that at the time when science especially in the field of education is not yet developed as recently happen, Sanusi Daris has implemented a different teaching method from most teachers at that time, that is more humane, contains service oriented to the importance of the students only. Principle and paradigm emotional intelligence are clearly seen in it.

Teaching basically give influence, and "influence is only found in people of leadership" (Agustian, 2002). Research has proven how big is the role of influence of respected person, whether it is a father or teacher, has maintained power to bring the children to grow and become a sympathetic grown up, having better social relationship and useful for the community (Gottman, 1997).

Figure of teacher such as one performed by Sanusi Daris will be an idol for all of the students anywhere and anytime. When education in Indonesia particularly in Duri, a very remote area, knowledge on science of education is still of embryonic phase, modern educational principles has already been practiced by Sanusi Daris. Most teachers at that time were produced by educational system of colonialism which tend to be more feudalistic.

\subsection{Sanusi Daris as a Fighter.}


Independence Proclamation read by Ir Soekarno on August 17, 1945 symbolized a new era for Indonesian people. Ever since, nation started to hold life of state and self-governance to run principles, basics, and missions on the independence as mandated in the preamble of UUD 45. The big happening was rapidly echoed throughout the whole country. Through the meaning of the proclamation, since then Indonesian nation expected to be able to run their own life. However, the fact told another, expectation and destiny as underlined in the Preamble of UUD 45 have to face heavy challenges. The remaining the Japan troops did pressure, as well as Dutch which ride with allied forces did various efforts in order to be able colonize Indonesia again (Hatta, 1982).

At that time Sanusi Daris who was a teacher in Malua joined with military troops under Puang Tambone. While teaching he together with young people of Duri took a part in various activities supporting fight maintaining independence.

Please note that at the beginning of war for independence there were so many organization in South Sulawesi named by the existing ethnics. "There were KRIS Mandar, BPRI, Ganggawa, Lapris, and so on. Then known TKR and TRI; later after state sovereignty is handed over then military organization system will be established" (Poelinggomang. 2000). Special for Duri, it was established Wolter Monginsidi Battalion for preparation leaded by Andi Sose. The Battalion was established by Andi Sose together with his friends after released from prison in Makassar. Andi Sose was the last descendant of Malua Kingdom (Zelfsbestur Anggeraja) who was selected to replace his father Puang Liu to be King of Anggeraja Kingdom, but he preferred to continue his study in Makassar and met Robert Wolter Monginsidi, Emmy Saelan, and many other figures who were the pioneer of independence fighter in South Sulawesi. When raised youth movement to maintain independence, Andi Sose also joined it.

Andi Sose was caught by NICA due to his activities in the youth movement. He was released from prison of Dutch in 1947. "After released, he took a part in a meeting in Paccekke to form Hasanuddin Division as mandated by the Big Commander Sudirman on January 17, 1947" (Tangke, 2005). Then he thought to come back to his village in Cakke (Duri) to organize youth there. Not long after that, came two delegations from Duri, they were Baco Kalla and Muhammad Husain. Muhammad Husain then became a leader of Momoc Hitam under Pawennai. Both men brought membership card of Merah Putih under the command of Harimau Indonesia to Tanah Duri. Upon arriving in Tanah Duri, Andi Sose established Wolter Monginsidi Battalion, part of Kesatuan Gerilya Sulawesi Selatan (KGSS) which then changed to Corps Cadangan Nasional (CCN).

In the Wolter Monginsidi Battalion, Sanusi Daris started his carrier as a troops commander. Signs of talented leader was starting to come up. In various happenings Sanusi Daris has shown characters of a leader who could bring respect and sympathy of his subordinates. Every time he went to travel for military operation, he was always the one in front and directly held the flag. In fact in the military regulation, a commander must be in the back line or in the middle of his troops.

As a troops commander, Sanusi Daris showed high empathy for this followers by understanding and realizing what they are experiencing. This attitude was a big capital for him in running his responsibility of the organization. Tasmara, (2006) mentioned that "an 
empathetic leader will be always proactive to look for motives or heart saying of his constituents which then create happily service leadership style (servant leader)." They are capable of stimulating positive emotion in the body of people leaded. Even, they are capable to detect and diagnose weakness and strength their constituents or subordinates. For leaders who posses high empathy, there is emotional involvement between them and all of human sources around them. His heart is always touched when he see the condition of the people under his command.

From here we can take the positive sides that a leader must be able to empathize and read the existing values and then offer vision at the same time solution to bring to the future of destiny. Must be able to articulate, explain with simple language, reasons why have to go certain place, what benefit will be obtained and how will be the people or institution being lead in the future.

\subsection{Sanusi Daris as an Agent of socio-cultural changes}

Sanusi Daris as the highest authority of DI-TII in Duri Complex have a big role in creating stability in the community under his leadership (DI-TII). In a quite long time, less or more than ten years, people of Duri under Darul Islam were starting to have strong belief on Islam. Most family members who migrated due to the conflict even started to implement Islamic social life by referring to the system introduced by Darul Islam. This was all because of the leadership of Sanusi Daris which was exact, consistent, trustworthy, and fresh to start the new change in life.

Although it was the time of conflict, persuasive methods were still applied to motivate community to keep implementing the new system. Speech of da'wah was intensively performed to socialize the implementation the teachings of Islam. The army or TII was only to run the function of control in order not to be found disobedience. The result could be seen by many in not so long time. Finally people started to feel comfortable with the new system. All life aspects have been regulated based on the teachings of Islam (Limbugau, 1993).

If we observe deeper about the success story how Darul Islam in establishing the new life based on the teachings of Islam, it was because of some factors, such as: the benefit of the Islamic teachings implementation felt by the people, for example the slowly fading of the deeds close to fornication, fraud, and honesty could be seen clearly in the daily life. Members of the community were getting close each other so that they came to the tighter bond and they were willing to help each other creating organized life of more efficient and productive way. It was so much different from their life before which was natural, more about the habit, and was not supported by the high consciousness and sincerity.

Rebellion was not quite in the feeling of the people anymore although they might be losing if military operation happen anytime, such as houses were burned along with its content by the troops, and forced to evacuate faraway in the high point of the hill with unfriendly nature. Together with the stabilized condition, behavior of TII became more accommodative and focused more to solve problem any member of the community.

Such condition for sure was not formed spontaneously, but through the thorough study of political condition and situation of the leaders in DI-TII under coordination of Sanusi Daris. As a follow up of the change in the approach of system, DI-TII started to establish school centered in Pangluburan of Salukanan village which is now known as Baraka district. There 
built schools starting from SR to senior high school.

And the plan to build higher education was not realized yet till came big military operation by Indonesia National Army (TNI). All power of DI-TII was deployed to face military operation to keep the existing dynamical movement proclaimed. At the same time of education institution establishment, civilian government structure was also prepared starting from the highest up to the village governance as well as to point the officials to sit in the provided positions. The structure was outside of the military structure so the formation was quite similar with civilian and military of the legal government.

\subsection{Sanusi Daris as a Leader of Charismatics}

Someone viewed as a charismatic leader by the community because he/she is considered as "a powerful and multi-talented figure, capable to handle any danger and challenge deal with the community" (Dirdjosisworo, 1985). However, it is not merely as it is, most charismatic leaders are they who have good deed, so it is more spiritual than technical. This is what traditional leadership so called as: "Ing ngarsa asung tulodo, Ing madya mangun karsa, Tut wuri Handayani”" (Soekanto, 1986).

If we trace back the leadership of Sanusi Daris to meet revolutionary demand, basically traditional teaching principles have been shown in his attitude and behavior. So everything spoken, suggested even prohibited was sincerely obeyed by his followers. He did not make much order, he gave good examples much more. If he prohibited something impolite, he only gave comparison and explanation the negative effects if we do something bad.

Leadership by giving example is considered to be more effective rather than giving order or force (Gonggong, 2002). In running his role Sanusi Daris more emphasizing in the gift of example, attention or empathy rather than using ways to manipulate interaction with readily designed communication style. One of his habit needs to be discussed here is that when Sanusi Daris meet his subordinates he is the one to greet first. In fact, this gave a deep impression on them whom greeted.

Such unique attitude is part of his various good manners, so that social structure he established could run smoothly although it was during war time. For example, when he became a teacher, his prominent attitude was his performance which was always caring, sincere, loving, and familiar. There was no nuance of showing authority though teacher was a very respected profession at the time. When he became a fighter till the time he was entitled various statuses in glorious time with DI-TII those behavior still could be seen. It may be that it is already part of his personality.

Ing madya mangun karso (in the middle, we can enhance spirit of others) currently so many people especially leaders do not care about it. Most of them only emphasize the aspect of authority to motivate their subordinates to work optimum work for maximum result. Many of them ignore his motivation. In fact "the real motivation is the strength to move someone's effort to reach optimum result" (Handoko, 1994).

From this perspective we see how many leaders who come to the stage lead ineffectively, even cons productive, give no result, except to exhibit their power which kill their constituents' spirit to do something based on their responsibility given. Subordinates are eager to go office when their leader is there, when the leader is not there their diligence gone. This is a truly decrease of productivity. Successful or not, effective or not of a leadership is 
dependent to the value or the organization or department being lead.

\section{Conclusion}

Research findings showed that Sanusi Daris was born and grown up in a community where an organized social system has been there, it was Duri community. Far before history began, "Duri Kingdom" has already found in that community area. Duri community pays special attention about leader recruitment. During his life history, Sanusi Daris has entitled various statuses, a teacher of $S R$ in his village, as member of youth movement when war to maintain independence was happening. Finally he leaved the battalion (Wolter Monginsidi Battalion) to join Kahar Muzakkar. Both proclaimed the establishment of DI-TII in Baraka.

Sanusi Daris was successful in making big change in socio-cultural life mainly in the religious system that is from animism dynamism to syariat Islam based on the Al-Quran and true Hadith, all aspect of socio-cultural life, economics, and politics were drastically changing.

Sanusi Daris was a figure of admiration and lovable in the eye of his followers and constituents or they who ever communicated with him. In the people's perception, he was a savior, protector, and unifier of community in the whole complete unity with the base principles of Islam. He was considered as a figure and elderly who is clean, honest, good role model, trustworthy so that his leadership was recognized and accepted.

\section{References}

Abdullah, M. S., (1986). Lontarak Duri (Rampunan Kada). Makassar: Hasanuddin University Abdullah, M. S., A. Gani dan H. Basri., (1987). Lontarak Enrekang milik: Puang La Sallang titled Puang Tobalu Pabbicara Enrekang Terakhir. Makassar: Hasanuddin University. Agustian, A. G., (2002). Rahasia Sukses Membangun Kecerdasan Emosi dan Spiritual. Jakarta: Arga.

Arikunto, S. (1996). Research a Procedure Practice Approach. Jakarta: Rineka Cipta.

Buapala, P. (2003). Struggle traces the Kings Tanduk Mataranna Masserempulu. Enrekang: governments Enrekang.

De Porte, B., M. Reardon, \& S. S., Nourie. (2002). Quantum Teaching. Bandung: Kaifa

De Potre, B., \& M. Hernacki. (2001). Quantum Learning. Bandung. Kaifa.

Gottman, J., \& Joan D., (1997). Tips Raising Children Who Have Emotional Intelligence. Jakarta: Gramedia Pustaka Utama.

Gonggong, A., (2002). Leadership: Perspectives Culture Collection. Presented at the Meeting of National Culture in Makassar on October 17-18

Hatta, M., (1982). Around Proclamation. Tintamas Indonesia. Jakarta: Rajawali.

Hasniati. (2006). Flow of Philosophy and Public Administration Research Methodology. Journal of Public Administration. No. 75 thing 35.

Handoko, M., (1994). Motivation Power Driving Behavior. Yogyakarta. Kanisius.

Limbugau, D., (1993). Islamization in the Kingdom of Duri. Presented at the Department of History and Archaeology, seminar on May 5. 1993

Ministry of Education \& Culture. (1979). F I R O. Jakarta: Directorate General of Higher Education Normalization of Campus Life Project. 


\section{Macrothink}

Muhadjir, N., (2006). Qualitative Research Methods. Yogyakarta: Rake Sarasin.

Mulyana, D. (2006). Qualitative Research Methodology New Paradigm of Communication Sciences and Social Sciences. Bandung: Rosdakarya.

Moleong, L. J., (1996). Qualitative Research Methods. Bandung: Remaja Rosdakarya. Pattan, and Patricia, (1998). EQ Relationships, The road to happiness and prosperity. translation Hermes - Malang. Jakarta: Pustaka Delapratasa.

Poelinggomang, E., (2006). Origins of Culture and Language Toraja. Seminar presented at the Cultural Park in Makassar on 28 October.

Rivai, V., (2004). Tips for Leading in the 21st Century.Jakarta: RajaGrafindo Persada.

Sialla, Z., (2005). Zainuddin Sialla., A Remembrance. not published. Makassar.

Soekanto, Soejono. 1983. Sociological Theory of Social Change. Jakarta: Ghalia Indonesia.

Stine, J. M., (2002). Double Your Brain Power. Jakarta. PT. Gramedia Pustaka Utama.

Tangke, A. W., 2005. Radical-Trace trail Kahar Muzakkar. Makassar. Pustaka Refleksi

Tasmara, Toto. 2006. Spiritual Centered Leadership. Jakarta: Gema Insani. 